\title{
Sustainability of the Environment: The Impact of Recycling in Obio-Akpor Local Government Area in Rivers State
}

\author{
Odunze Wisdom C.N., Nwikpo Joy Legborsi
}

\begin{abstract}
Recycling is greatly felt on both Local and National scale in Nigeria as a central aspect in sustainability and mainly as pro-environmental consumer behavior. The paper assesses the impact of recycling in obio-Akpor local government area. Through my literature review and participant observation, Qualitative approach was used in data collection and stratified random sampling was used to select respondents. Random sampling was used to administer 203 questionnaires to the masses; Descriptive statistic was used to analyze the impact and benefit of recycling. The result indicates that recycling has significant impact on environmental sustainability in Obio-Akpor in Rivers State therefore requires an urgent need to educate the masses about mitigation strategies for sustainable development such as waste recycling, reduce, re-use materials to ensure that our environment is cleaner, healthier and a greener place to live. These strategies will help to guarantee a sustainable future where our economy can thrive and good health is fostered across every border.
\end{abstract}

Index Terms - Recycling, Waste Generation, Solid Waste Management and Environmental Sustainability.

\section{INTRODUCTION}

The generation and disposal of waste is an intrinsic part of any developing or industrial society. Waste, both from domestic and commercial sources has grown significantly in Nigeria over the past decade. Every time a householder shops at the store, an open market, etc it contributes to the mountain of waste. It is possible to quote figures which show that the production of waste amounts to millions of tons. The percentage of Nigeria's population living in cities and urban areas has doubled as compared to the percentage in the last 15 years. The cities and urban areas experience continuous growth which contributes to enormous generation of solid and liquid waste. The management of waste is a matter of national and international concern. The volume of waste does not actually constitute the problem but the ability or inability of governments, individuals and waste disposal firms to keep up with the task of managing waste and the environment. There is no doubt that a dirty environment affects the standard of living, aesthetic sensibilities, health of the people and thus the quality of their lives. The outcome is that improper disposal or storage of this waste can constitute hazards to the

Odunze Wisdom C.N. Ph.D, Department of Environmental Sciences, Imo State Polytechnic, Umuagwo

Corresponding Authour:drmrswisdomodunze@gmail.com

Nwikpo Joy Legborsi, Dept. of Environmental Science and Resource Management, National Open University of Nigeria society through the pollution of air, land and water especially.

One of the processes of solid waste management adopted is landfill, this process has been overstressed and the resultant effect is that landfills in many cities in Nigeria are currently facing a critical condition in managing the domestic solid waste (Adefemi \& Awokunmi 2009). Port Harcourt was known as the garden city in the 1970s but is now known as garbage city because of poor waste management practices. The 2010 report of the World Health Organization (WHO, 2010) indicate that there are over 500 landfills in Nigeria. Most of these landfills site are operated by the process of the open dumping system (Abd'Razack et al 2013). The attendant effect of the long period of open-dumps landfills is the pollution of the environment, especially water and air (Adebola, 2006). The best method of waste management should therefore be sanitary landfills, which are more environmentally friendly than the open dump landfill system currently in use. There are only few sanitary landfills in Nigeria operated by state such as Lagos, Kano and Cross Rivers (Agwu, 2012)

Recycling depends on waste materials which cannot be reused directly but can be converted to new product or raw material through the processes of transformation. For instance, used paper is recycled into files, envelops and cards. Energy is recovered through recycling through: pyrolysis (combustion of waste in the absence of oxygen to create gases, liquids and solid compounds), incineration (combustion in the presence of oxygen to produce oxidized compounds), anaerobic digestion, gasification and pelletization; as well as composting (biological and chemical degradation of organic waste in large centralized, small enterprise, backyard or household basis). Together, the '3Rs' aimed at achieving sustainable solid waste management; and, also relates to other global environmental challenges, particularly, climate change mitigation, specifically, the emission of greenhouse gases that could create sustainable development co-benefits and reduction in the emissions of methane $(\mathrm{CH} 4)$, biogenic carbon dioxide (CO2), non-methane volatile organic compounds (NMVOCs), nitrous oxide (N2O), nitrogen oxide (NOx) and carbon monoxide (CO) from landfills. The observations of recycled households and non recycle households in the direction of recycling benefits were also evaluated. According to Wright 2011, analysis of research findings has indicated a flawless relationship between attitudes to recycling and waste reduction in American society, concentrating on both individuals and society on their feeling about waste recycling and the environment. 
In this research, our attention would be focused on domestic waste. We will highlight some of the problems which have attended the management of this category of waste in Nigeria today. It will be seen that Nigeria has not done well in the direction of tackling the menace of domestic waste. This is even in the face advanced management strategies existing today for domestic waste management which have been adopted in many places. We will proffer suggestions that may assist in addressing this issue that seems to be aborting most efforts of International organizations, the federal government, city authorities, states and professionals alike.

\section{A. Statement of the Problem}

Wastes pose serious environmental and health problems, promote insect vectors like mosquitoes and flies (Cairncross and Feachem 1993), rats and mice, cause fire hazards, flooding of streams, odor problems, nuisance in Port Harcourt metropolis owing to the lack of awareness and proper planning in the selection of dump sites by authorities. If not properly manage can be disastrous. The non-biodegradable ones are even more dangerous because they persist in the environment for many years. In Nigeria, the commonly practiced waste management option basically involves the collection of mixed waste materials and subsequent dumping at designated dumpsites. Hence, wastes are not separated at source or any point during its management (Adekunle et al, 2011). Development is needed to enhance the quality of the lives of citizens in a country since developmental projects affect the environment and ecology. Therefore for the past decades people have been talking about sustainable development. The concept of sustainable development attracted significant attention from researchers, governments of different countries and international environmental organizations. The reason is lucid, that is, the increased rate of environmental pollution and degradation. Since poor waste disposal habit of the people, weak government regulation, poor work attitude, lack of fund, inadequate facilities such as plants and equipment among others are factors militating against effective waste management towards sustainable development in Nigeria. One such way of managing these categories of waste is by recycling It is on these premises that the researcher intends to investigate the impact of recycling on sustainability of the environment:.

\section{B. Objectives of the Study}

The aim of the study is to ascertain Impact of Recycling on the Sustainability of the Environment in Port Harcourt Metropolis. This aim can be achieved with the following objectives:

* To evaluate the perception of people about recycling

* To evaluate the impact of recycling on environmental sustainability.

* To evaluate the relationship between solid waste management and environmental sustainability

* To suggest mitigate measures to enhance sustainability in recycling waste

\section{Research Questions}

* To what extent are people aware of recycling in Obio Akpor LGA?

* To what extent does waste generation impact on environmental in Obio-Akpor LGA?

* What is the nature of relationship between environmental sustainability and waste management system in Obio-Akpor LGA?

* What are the mitigating measures to enhance sustainability in recycling waste?

\section{Research Hypotheses}

For the successful completion of the study; the following research hypotheses was formulated;

$\mathbf{H}_{\mathbf{0}}$ : There is no relationship between solid waste management and environmental sustainability

$\mathbf{H}_{\mathbf{1}}$ : There is a relationship between solid waste management and environmental sustainability

\section{E. Significance of the Study}

The findings will be of great importance to the Federal Ministry of Environment, General public and Waste Management Agencies. Empirically, the outcome of this research will enable the general public and Government to grasp deeply the hazardous effect of reckless disposal of waste alongside every nook and cranny of the nation and factors that impede/hamper the implementation of waste management and recycling as a means of managing solid waste in Obio-Akpor LGA in Rivers State. The findings will also be of great importance to the Environmental Management Agency as the findings will aid them in developing a model to check and control solid waste management through the recycling process. The study will also be of importance to researchers who intend to embark on studies in similar area. Finally the study will be of great importance to academia's as the study will add to the body of knowledge

\section{F. Area of Study}

The study area was within Obio-Akpor which is a local government area in the metropolis of Port Harcourt, one of the major centres of economic activities in Nigeria, and one of the major cities of the Niger Delta, located in Rivers State. The local government area covers $260 \mathrm{~km}^{2}$ and at the 2006 Census held a population of 464,789 . Its postal code or ZIP code is 500102. Obio-Akpor has its headquarters at Rumuodomaya. The original indigenous occupants of the area are the Ikwerre people. Obio-Akpor is bounded by Port Harcourt (local government area) to the south, Oyigbo to the east, Ikwerre to the north, and Emohua to the west. It is located between latitudes $4^{\circ} 45^{\prime} \mathrm{N}$ and $4^{\circ} 60^{\prime} \mathrm{N}$ and longitudes $6^{\circ} 50^{\prime} \mathrm{E}$ and $8^{\circ} 00^{\prime} \mathrm{E}$. The climate of the area is basically that of the tropical equatorial latitude with rainfall occurring almost throughout the year except December, January and February. This short dry period is characterized by the dusty winds northeast trade being a period of severe dryness. The 
temperature of $25^{0} \mathrm{C}-28^{\circ} \mathrm{C}$ throughout the year is relatively constant, and a mean annual precipitation of $2500 \mathrm{~mm}$ (Gobo, et,al., 2008).

\section{RECYCLING}

Waste Recycling is a process of converting waste materials into new products to prevent waste of potentially useful materials, partly supplement the consumption of fresh raw materials, reduce energy usage (almost $70 \%$ less energy is required in recycling), reduce air pollution from incineration and water pollution from land filling by reducing the need for conventional waste disposal, and lower greenhouse gas emissions (Basel Convention 1989 waste recycling bank ind.), Wikipedia (2019) Recycling.

According to Ezeah, C; Roberts C. L. 2012, Nigeria typifies the many developing countries that have done less in implementing sustainable solid waste management due to the numerous barriers impeding municipal solid waste management. One of these barriers is the absence of a formal recycling platform. Schill, M; Shaw, D. 2016, said Recycling is viewed as a fundamental aspect in sustainable waste management and mainly as pro-environmental consumer behaviour; because of this sustainability and recycling behavior are intertwined. As sustainability and recycling behavior are interrelated, it is relevant to examine the impact of recycling of waste in Obio-Akpor LGA in Rivers State.

\section{A. . Types of Recycling}

Recycling can be distinguished into three different forms such as closed-loop recycling, open-loop recycling and down loop recycling which is defined as follows (Lox 1994):

"Close-Loop Recycling is a recycling process in which a waste material is used for the same purpose as original purpose or for another purpose requiring at least as severe properties as the previous application so that, after one or several uses, this material can be used back again for original purpose"

“Open-Loop Recycling is a recycling process in which a waste material is used for another purpose than the original purpose and will never be used back again for the original purpose"

"Down-Loop Recycling is a recycling process in which a (fraction of a) material from a used product is used to make a product that does not require a severe properties as the previous one."

\section{B. The Impact of Recycling on the Sustainability of the Environment}

Recycling is the process of converting waste materials into new materials and objects. It is an alternative to "conventional" waste disposal that can save material and help lower greenhouse gas emissions (compared to plastic production, for example). Recycling can prevent the waste of potentially useful materials and reduce the consumption of fresh raw materials, thereby reducing: energy usage, air pollution (from incineration), and water pollution (from land filling). Recycling is a key component of modern waste reduction and is the third component of the "Reduce, Reuse, and Recycle" waste hierarchy. Most common products recycled include Aluminium, Beverage can, $\mathrm{Cu}$, steel, tyres, polyethylene \& PET bottles, glass bottles, corrugated sheets, paper board, newspaper. The type of material accepted for recycling varies by city and country (Wikipedia 2019). However certain variation in acceptance is reflected in the resale value of the material being reprocessed (Walker, 2018). During the 1980s recycling took a much greater significance than just providing an alternative method for treatment of solid waste.

Source reduction and recycling became an American's popularly accepted methods for waste management. In US, recycling rate of MSW is about $22 \%$ (USEPA, 2001). Public education is very crucial for a successful recycling programme.

There are certain benefits associated with waste recycling. These include:

It saves precious finite resources, Lessen the needs for mining of virgin materials which lowers the environmental impact of mining and processing, It reduces the amount of energy consumed, It improves the efficiency and ash quality of incineration and composting facilities by removing non-combustible materials such as metals and glass.

\section{RESEARCH METHODOLOGY}

\section{A. Sources of Data Collection}

Data were collected from two main sources namely: Primary data and Secondary data. Primary data was

Gathered through a self-developed questionnaire and Secondary data were collected from literature, textbook, Journal etc.

\section{B. Population of the Study}

Population of a study comprised of residents of Obio-Akpor, in Rivers State, Nigeria. This consists of individual who are knowledgeable about the subject matter and are willing to share their knowledge with the researchers. The estimated population of Obio-Akpor is 203.

\section{Sample and Sampling Procedure}

The study employed a stratified random technique. This approach guaranteed precision of the samples by avoiding sampling error.

\section{Instrument for Data Collection}

The major research instrument used is the questionnaires. The questionnaire was designed to obtain sufficient and relevant information from the respondents. The primary data contained information extracted from the questionnaires in which the respondents were required to give specific answer to a question by using Agree, Strongly Agree, Neutral, Disagree and Strongly Disagree: The questionnaires contained about 50 structured questions which were divided into sections $A$ to $G$. The respondents filled and completed the questionnaire on the spot.

\section{E. Reliability of the Instrument}

The test re-test technique of reliability was used to assess the reliability of the research instrument. The questionnaires 
were administered to the pilot sample respondents twice with a week interval after which a correlation was taken between the two tests to estimate the reliability of the questionnaire. The Pearson correlation coefficient was used to estimate correlation coefficient of the two tests using the formula.

\section{F. Method of Data Analysis}

Data collected were analysed using the Statistical Package for the Social Science (SPSS) Software. Primary data for the study were analysed using descriptive (cross tabulation, frequency, percentage, mean, and standard deviation) and A Pearson Chi-Square Test.

\section{RESULTS AND DISCUSSIONS}

In this chapter, the collected data were analyzed, presented and discussed in the light of the study objectives.

\section{A. Socio Demographic Characteristics of Respondents}

This section presents the socio demographic characteristics of respondents in the study. The socio demographic characteristics under consideration are gender, age, highest educational level, nature of job, number of years lived in the city.

Table 1: Table Displaying the Distribution of Gender of Respondents

\begin{tabular}{|ll|l|l|}
\hline & & Frequency & Percent \\
\hline \multirow{3}{*}{ Gender } & Male & 111 & 54.7 \\
& Female & 92 & 45.3 \\
& Total & 203 & 100.0 \\
\hline
\end{tabular}

The Table 1 shows that out of the Two hundred and three respondents that responded to the questionnaire, 111(54.7\%) were males, $92(45.3 \%)$ were females.

Table 2: Table Displaying the Distribution of Age of Respondents

\begin{tabular}{|ll|l|l|}
\hline & & Frequency & Percent \\
\hline \multirow{4}{*}{ AGE } & $18-29$ & 82 & 40.4 \\
& $30-39$ & 73 & 36.0 \\
& $40-49$ & 42 & 20.7 \\
& $50-59$ & 3 & 1.5 \\
& $60-64$ & 3 & 1.5 \\
& Total & 203 & 100.0 \\
\hline
\end{tabular}

The Table 2 shows that out of the Two hundred and three respondents that responded to the questionnaire, $82(40.4 \%)$ were between age 18 and 29, $73(36.0 \%)$ between age 30 and $39,42(20.7 \%)$ between 40 and $49,3(1.5 \%)$ between age 50 and 59 and $3(1.5 \%)$ between age 60 and 64
TABLE 3: TABLE DISPLAYING THE DISTRIBUTION OF HIGHEST EDUCATIONAL LEVEL OF RESPONDENTS

\begin{tabular}{|l|l|l|}
\hline & Frequency & Percent \\
\hline Secondary School & 4 & 2.0 \\
Undergraduate & 62 & 30.5 \\
University Graduate & 120 & 59.1 \\
Vocational Training & 17 & 8.4 \\
Total & 203 & 100.0 \\
\hline
\end{tabular}

As indicated in Table 3 above, out of the Two hundred and three respondents, $4(2.0 \%)$ are secondary school holders, 62 $(30.5 \%)$ are undergraduates, $120(59.1 \%)$ are university graduates and $17(8.4 \%)$ are into vocational training.

Table 4 Table Displaying the Distribution of Major Occupation of Respondents

\begin{tabular}{|ll|l|l|}
\hline & & Frequency & Percent \\
\hline \multirow{4}{*}{ Occupation } & Business & 28 & 13.8 \\
& Civil Servant & 42 & 20.7 \\
& Others & 129 & 63.5 \\
& Farmers & 4 & 2.0 \\
& Total & 203 & 100.0 \\
\hline
\end{tabular}

The results as presented in Table 4 shows that out of the Two hundred and Three respondents, 28 (13.8\%) are into business, $42(20.7 \%)$ are civil servants, 129 (63.5\%) are into other professions, $4(2.0 \%)$ are farmers.

Table 5 Table Displaying the Distribution of Length of Years Respondents have lived in a City

\begin{tabular}{|c|c|c|c|}
\hline & & Frequency & Percent \\
\hline \multirow{7}{*}{$\begin{array}{l}\text { Years Spent in } \\
\text { the City }\end{array}$} & Less than a year & 4 & 2.0 \\
\hline & $1-2$ years & 16 & 7.9 \\
\hline & -4 years & 12 & 5.9 \\
\hline & $5-9$ years & 31 & 15.3 \\
\hline & 10-19 years & 99 & 48.8 \\
\hline & 20 years or more & 41 & 20.2 \\
\hline & Total & 203 & 100.0 \\
\hline
\end{tabular}




\section{B. Analysis of Responses to Research Questions}

Research Question 1: Are respondents aware of recycling in Obio Akpor ?

Table 6 Descriptive Analysis of Responses on their awareness on Recycling

\begin{tabular}{|ll|l|l|}
\hline & & Frequency & Percent \\
\hline \multirow{4}{*}{ Valid } & Agree & 128 & 60.7 \\
& Stongly Agree & 71 & 33.6 \\
& Strongly Disagree & 4 & 1.9 \\
Total & Total & 203 & 96.2 \\
\hline
\end{tabular}

Source: Researchers field work (2019)

Table 6 shows that the responses of respondents on their awareness of recycling. From research question one, it is observed that the percentage of those who agree is $60.7 \%, 33.6 \%$ strongly agree, $0 \%$ neutral, $0 \%$ disagree and $1.9 \%$ strongly disagree. This however revealed that most of the respondents have heard about recycling before.

Table 7 Descriptive Analysis of Responses on their correct awareness on recycling

\begin{tabular}{|c|c|c|c|c|c|c|}
\hline & Agree & Strongly Agree & Neutral & Disagree & $\begin{array}{l}\text { Strongly } \\
\text { Disagree }\end{array}$ & Total $(\%)$ \\
\hline $\begin{array}{l}\text { Over packaging disposable } \\
\text { and throw products degrades } \\
\text { environment }\end{array}$ & $130(64.0 \%)$ & $61(30.0 \%)$ & $0(0 \%)$ & $8(3.9 \%)$ & $4(2.0 \%)$ & $203(100 \%)$ \\
\hline $\begin{array}{l}\text { Solid waste constitute a } \\
\text { serious health problem }\end{array}$ & $94(46.3 \%)$ & $93(45.8 \%)$ & $11(5.4 \%)$ & $5(2.5 \%)$ & $0(0 \%)$ & $203(100 \%)$ \\
\hline $\begin{array}{l}\text { People near waste dumps and } \\
\text { landfills are suffering from } \\
\text { respiratory problems eye } \\
\text { diseases and water borne } \\
\text { diseases }\end{array}$ & $54(26.6 \%)$ & $136(67.0 \%)$ & $13(6.4 \%)$ & $0(0 \%)$ & $0(0 \%)$ & $203(100 \%)$ \\
\hline $\begin{array}{l}\text { Animals, Rodents Scavenging } \\
\text { through waste dumps spread } \\
\text { diseases }\end{array}$ & $50(24.6 \%)$ & $146(71.9 \%)$ & $7(3.5 \%)$ & $0(0 \%)$ & $0(0 \%)$ & $203(100 \%)$ \\
\hline $\begin{array}{l}\text { Improper waste management } \\
\text { leads to water and air } \\
\text { pollution which is a serious } \\
\text { environmental problem }\end{array}$ & $34(16.7 \%)$ & $169(83.3 \%)$ & $0(0 \%)$ & $0(0 \%)$ & $0(0 \%)$ & $203(100 \%)$ \\
\hline Solid waste is a social menace & $116(57.1 \%)$ & $65(32.0 \%)$ & $14(6.9 \%)$ & $8(3.9 \%)$ & $0(0 \%)$ & $203(100 \%)$ \\
\hline Average & $79.67(39.3 \%)$ & $111.67(55 \%)$ & $7.5(3.7 \%)$ & $3.5(1.7 \%)$ & $0.67(0.3 \%)$ & $203(100 \%)$ \\
\hline
\end{tabular}

Research Question 2: Does Solid Waste have Impact on the Environment?

Table 8 Descriptive Analysis of Responses on the Impact of Solid Waste on the Environment

\begin{tabular}{|c|c|c|c|c|c|c|}
\hline & Agree & Strongly Agree & Neutral & Disagree & $\begin{array}{l}\text { Strongly } \\
\text { Disagree }\end{array}$ & Total $(\%)$ \\
\hline $\begin{array}{l}\text { Over packaging disposable } \\
\text { and throw products degrades } \\
\text { environment }\end{array}$ & $130(64.0 \%)$ & $61(30.0 \%)$ & $0(0 \%)$ & $8(3.9 \%)$ & $4(2.0 \%)$ & $203(100 \%)$ \\
\hline $\begin{array}{l}\text { Solid waste constitute a } \\
\text { serious health problem }\end{array}$ & $94(46.3 \%)$ & $93(45.8 \%)$ & $11(5.4 \%)$ & $5(2.5 \%)$ & $0(0 \%)$ & $203(100 \%)$ \\
\hline
\end{tabular}


Sustainability of the Environment: The Impact of Recycling in Obio-Akpor Local Government Area in Rivers State

\begin{tabular}{|l|l|l|l|l|l|l|}
\hline $\begin{array}{l}\text { People near waste dumps and } \\
\text { landfills are suffering from } \\
\text { respiratory problems eye } \\
\text { diseases and water borne } \\
\text { diseases }\end{array}$ & $54(26.6 \%)$ & $136(67.0 \%)$ & $13(6.4 \%)$ & $0(0 \%)$ & $0(0 \%)$ & $203(100 \%)$ \\
\hline $\begin{array}{l}\text { Animals, Rodents Scavenging } \\
\text { through waste dumps spread } \\
\text { diseases }\end{array}$ & $50(24.6 \%)$ & $146(71.9 \%)$ & $7(3.5 \%)$ & $0(0 \%)$ & $0(0 \%)$ & $203(100 \%)$ \\
\hline $\begin{array}{l}\text { Improper waste management } \\
\text { leads to water and air } \\
\text { pollution which is a serious } \\
\text { environmental problem }\end{array}$ & $34(16.7 \%)$ & $169(83.3 \%)$ & $0(0 \%)$ & $0(0 \%)$ & $0(0 \%)$ & $203(100 \%)$ \\
\hline Solid waste is a social menace & $116(57.1 \%)$ & $65(32.0 \%)$ & $14(6.9 \%)$ & $8(3.9 \%)$ & $0(0 \%)$ & $203(100 \%)$ \\
\hline Average & $79.67(39.3 \%)$ & $111.67(55 \%)$ & $7.5(3.7 \%)$ & $3.5(1.7 \%)$ & $0.67(0.3 \%)$ & $203(100 \%)$ \\
\hline
\end{tabular}

Source: Researchers field work (2019)

Table 4.8 shows that the responses of respondents on the impact of solid waste on the environment. From research question one, it is observed that the percentage of those who agree that sold waste, when not recycled have impart on the environment is $39.3 \%, 55 \%$ strongly agree, $3.7 \%$ neutral, $1.7 \%$ disagree and $0.3 \%$ strongly disagree. This however revealed that solid waste has negative impact on the environment due to high proportion of strongly agree and agree.

Table 9 Descriptive Analysis on Impact of Waste Recycling on Sustainability

\begin{tabular}{|l|l|l|}
\hline & Frequency & Percent \\
\hline Agree & 95 & 46.8 \\
& & \\
Stongly Agree & 90 & 44.3 \\
Neutral & 14 & 6.9 \\
Disagree & 4 & 2.0 \\
Total & 203 & 100.0 \\
\hline
\end{tabular}

Table 9 shows that the responses of respondents on the impact of waste recycling on environmental sustainability. From the table, it is observed that the percentage of those who agree that solid waste has impact on the environmental sustainability is $46.8 \%$, $44.3 \%$ strongly agree, $6.9 \%$ neutral, $2.0 \%$ disagree. This however revealed that recycling solid waste has impact on the sustainability of the environment.

Research Question 4: What are the measures to enhance Sustainability in Recycling Waste

Table 10 Descriptive Analysis on Waste Management is Sole Responsibility of Government

\begin{tabular}{|ll|l|l|}
\hline & Frequency & Percent \\
\hline \multirow{6}{*}{ Valid } & Agree & 91 & 44.8 \\
& Strongly Agree & 31 & 15.3 \\
& Neutral & 20 & 9.9 \\
& Disagree & 41 & 20.2 \\
& Strongly Disagree & 20 & 9.9 \\
& Total & 203 & 100.0 \\
\hline
\end{tabular}

Table 10 above shows that the responses of respondents on whether waste management is the sole responsibility of the government. From the table, it is observed that the percentage of those who agree that Improper waste disposal should attract punishment is $44.8 \%, 15.3 \%$ strongly agree, $9.9 \%$ neutral, $20.2 \%$ disagree. This however revealed that most respondents agree that waste management is the sole responsibility of the government.

Table 11 Descriptive Analysis of Response on Improper Waste Disposal Attracts Punishment

\begin{tabular}{|l|l|l|}
\hline & Frequency & Percent \\
\hline Agree & 137 & 67.5 \\
Strongly Agree & 37 & 18.2 \\
Neutral & 21 & 10.3 \\
Disagree & 8 & 3.9 \\
Total & 203 & 100.0 \\
\hline
\end{tabular}

Table 11 above shows that the responses of respondents on whether waste management is the sole responsibility of the government. From the table, it is observed that the percentage of those who agree that Improper waste disposal should attract punishment is $67.5 \%, 18.2 \%$ strongly agree, $10.3 \%$ neutral, $3.9 \%$ disagree. This however revealed that most respondents agree that waste management is the sole responsibility of the government.

Table 12 Descriptive Analysis of Response on Waste Collection Should Have Fixed Period

\begin{tabular}{|l|l|l|}
\hline & Frequency & Percent \\
\hline Agree & 119 & 58.6 \\
Strongly Agree & 72 & 35.5 \\
Disagree & 8 & 3.9 \\
Strongly Disagree & 4 & 2.0 \\
Total & 203 & 100.0 \\
\hline
\end{tabular}


Table 12 above shows that the responses of respondents on whether waste collection should have fixed period. From the table, it is observed that the percentage of those who agree that waste collection should have fixed period is $58.6 \%$, $35.5 \%$ strongly agree, $3.9 \%$ neutral, $2.0 \%$ disagree. This however revealed that most respondents agree that waste collectionn should have fixed period.

\section{TEST OF HYPOTHESIS}

In this section, the stated hypothesis for the study as tested. The hypothesis is stated as

H0: There is no significance relationship between Solid Waste Recycling and Environmental Sustainability.

H1: There is significance relationship between Solid Waste Recycling and Environmental Sustainability.

Table $10 \chi 2$ test on the relationship between Solid Waste Recycling and Environmental Sustainability. Chi-Square Tests

\begin{tabular}{|l|l|l|l|}
\hline & Value & df & $\begin{array}{l}\text { Asymp. Sig. } \\
(2-\text {-sided })\end{array}$ \\
\hline Pearson Chi-Square & $222.144^{\mathrm{a}}$ & 6 & .000 \\
Likelihood Ratio & 58.642 & 6 & .000 \\
$\begin{array}{l}\text { Linear-by-Linear } \\
\text { Association }\end{array}$ & 8.615 & 1 & .003 \\
\hline N of Valid Cases & 203 & & \\
\hline
\end{tabular}

A Pearson Chi-Square Test was carried out on relationship between solid waste management and environment sustainability. The cross tabulation of indicated that there is relationship between solid waste management and environmental sustainability [Pearson $\chi^{2}(\mathrm{df}=6, \mathrm{~N}=203)=$ 222.144, $\mathrm{p}=0.00]$.

Furthermore, the table shows that the Linear-by - Linear association (LLA) is significant [LLA, $(\mathrm{df}=1, \mathrm{~N}=203)=8.615$, $\mathrm{p}=0.003]$.

Decision: Since the p-value of the Chi-Square statistics $(0.00)$ is less than 0.05 significance level, the null hypothesis is rejected and the alternative hypothesis accepted. This implies that there is relationship between solid waste management and environmental sustainability.

Carrying out a Post Hoc analysis on the data, since it has been found that there is relationship between solid waste management and environmental sustainability, the Linear-by - Linear association (LLA) with $p=0.003$ is less than 0.05 significance level which indicates that as solid waste management is increased, then environmental sustainability is more ensured.

\section{Discussion of Findings}

The discussions of the findings of his study are discussed under the following sub-headings in line with the research questions;

Research Question 1: To what extent are people aware of recycling in Obio Akpor LGA?

The analysis of this study carried out showed that high proportion of the respondents has heard about recycling before. This finding is in line with the findings of Awopetu et.al (2013) which revealed a very high degree of awareness of the importance of solid waste reduction in the fight against the problems of waste management across Makurdi in which more than $65 \%$ of the residents under study agreed that solid waste can be reduced, reused and recycled. The study also showed whether the respondents are correctly aware of the possibility of having some wastes recycled. The result from the analysis showed that the respondents are well informed.

Research Question 2: To what extent does waste generation impact on environmental in Obio-Akpor LGA?

In Table 8 , the analysis of the data showed that waste generated and not recycled has a negative impact on the environment in Obio Akpor LGA. The responses shows that wastes that are generated and not well handled poses threat to health through spreading of diseases, degrades the environment, causes pollution both air and water e.t.c. this is in line with findings of Ejaz et.al(2010) where he found that an inefficient municipal solid waste management system may create serious negative environmental impacts like infectious diseases, land and water pollution, obstruction of drains and loss of biodiversity.

Research Question 3: What is the nature of relationship between environmental sustainability and waste management system in Obio-Akpor LGA?

Using the results obtained in Table 9, we discovered that waste recycling has impact on environmental sustainability in Obio Akpor LGA. This was further tested using the Chi-Square test. The results showed a relationship/dependency between waste management system and environmental sustainability. The Linear to Linear Association test revealed the type of relationship. It showed that as waste management system is encouraged, environmental sustainability is ensured. This is in line with the findings of Giovanis(2014) who studied the relationship between recycling rates of solid waste and air pollution. He discovered that as natural resources are conserved, the amount of pollution released into the environment is reduced

Research Question 4: What are the mitigating measures to enhance sustainability in recycling waste?

From Table10, we discovered that government is the one responsible for waste recycling in Obio Akpor LGA. This finding is not in line with that of Ogunniran(2019) where she found that waste management is the responsibility of both the government and private sector. Also, the Table 12 showed that, in order to sustain recycling of waste, waste collection should have a fixed period. This will enable household to properly bag their waste, while they await the waste collectors. Table 11 revealed that punishment should be meted to defaulters (i.e. those who inappropriately dispose their waste). This falls in line with Okoye et.al(2015) findings who recommended disciplinary measures to be taken against students who failed to manage their waste nor properly dispose them. She believed this will curb indiscipline amongst the students and which in turn will sustain the environment. 


\section{SUMMARY, CONCLUSIONS AND RECOMMENDATIONS}

The findings in this research work are discussed based on the parameters used for measurements. This study makes inferences which are in the form of conclusions from the collected and analyzed data in the work, and recommendations were made where necessary.

\section{A. Summary}

This study gives an overview of the study under the following subheadings; background of the study, statement of research problem, aim and objectives of the study, research questions, research hypothesis, significance of the study, scope of the study and definition of terms.

The study attempts to review various related scholarly works which were done in this field under investigation and outlines the techniques employed in collecting the required data. It deals with the methods employed in getting this research done. It has the following subheadings; research design, population for the study, sample and sampling techniques, nature and source of data, data collection method, data analysis and validation of Instrument.

The analysis of research questions was done and the formulated research hypothesis earlier stated and the findings of the results were extensively discussed.

\section{CONCLUSION}

This research work examined Sustainability of the Environment, the Impact of Recycling in Obio-Akpor LGA in Rivers state. From the findings, the researchers concluded that proper solid waste management (recycling) has impact on the sustainability of the environment in Obio Akpor Local Government Area.

\section{RECOMMENDATIONS}

The following specific recommendations are made based on the findings in this study:

1. Effective awareness of recycling should be encouraged to enable citizens to manage the waste generated in their homes which in turn enhances environmental sustainability
2. Proper dumping sites should be developed, far away from residential area where these waste products will be properly managed

3. Government should pass some laws which will checkmate the way used products are dumped. Environmental Sanitation should be encourage and participatory.

\section{REFERENCES}

[1] Abd'Razack, (2013). An appraisal of solid waste generation and management in jalingo city, Nigeria. Journal of Environmental and earth Science, 3(9), 20-28. ISSN 2224-3216 (paper)

[2] Adebola, O. O. (2006). The Role of Informal Private Sector in Integrated Solid Waste Management (ISWM) in Lagos, Nigeria - A Developing Country. Philadelphia P.A, Proceeding of the $21 \mathrm{st}$ International Conference on Solid Waste Technology and Management, 1(1): 1-8.

[3] Adefemi, S.O. \& Awokunmi, E.E. (2009). The Impact of municipal solid waste disposal in Edo-Ekiti, metropolis, Ekiti State, Nigeria... Cited in http://www.academijournal.org/AJEST/PDF. Retrived on 2nd June 2011

[4] Adekunle 2011. Recycling of organic wastes through composting for land

[5] Agwu, M.O. (2012). Issues and challenges of solid waste management practices in Port Harcourt City Nigeria; A behavioural perspective. American Journal of Social and Management Sciences, 3(2), 83-92.

[6] Basel Convention (1989) Waste Recycling. Bank Ind.

[7] Cairncross and Feachem 1993. Environmental Health Engineering in the Tropics; an Introductory text $2^{\text {nd }}$ edition

[8] Ezeah, C.; Robert, C.L. analysis of barriers and success factors affecting the adoption of sustainable management of municipal solid waste in Nigeria. J. Environ. Mang. 2012, 103, 9-14. \{Google Scholar\} \{Cross Ref $\{$ PubMed

[9] Gobo 2008. Estimating the Impacts of Climate Change and Urbanization

[10] Schill, M.; Shaw, D. Recycling today, Sustainability tomorrow; Effects of psychological distance on behavioural practice. Eur. Manag, J. 2016, 34, 349-362. \{Google Scholar\} \{Cross Ref\}

[11] Lox F (prom). (1994). Waste Management-Life Cycle Analysis of packaging.

[12] USEPA (2001)

[13] WHO (2010). Population Health and Waste Management; Scientific Data and Policy Option; Report of WHO workshop

[14] Wikipedia (2019) Recycling

[15] Wikipedia (2019) Waste

[16] Wright Y. L. (2011). Relating recycling; demographics, attitudes, knowledge and recycling behavior among: UC Berkeley students. 